\title{
A Failure of Praxis? European Revolutionary Anarchism in Revolutionary Situations, 1917-1923
}

\author{
Jason Garner \& José Benclowicz.
}

The Russian revolution of 1917 and the social conflict of the immediate post-First World War period created numerous revolutionary, or potentially revolutionary, situations. Anarchists were active in all of these situations in Germany, France, and Hungary but specifically in Russia itself, Italy, and Spain. The results of their participation were not encouraging: Bolshevik consolidation in Russia; fascist dictatorship in Italy; military dictatorship in Spain and elsewhere in Europe. Anarchist influence on the social struggles had been at best a secondary issue. By 1923, the movement was in decline, facing repression across the continent, with militants imprisoned, in exile, or murdered. Anarchist history has been "buried under subsequent defeats ... when not effaced altogether by its rivals on the Left," with much of the initial analysis of its historical role clouded by ideological bias, specifically by Marxists whose subjective conclusions have long been refuted by historians who have shown the predominantly urban and "proletarian social base of anarchism."1 The decline of revolutionary anarchism is generally treated in labour movement historiography as a logical result of the development of a centralized and/or democratizing state in which the working masses were attracted to movements that seemed more in tune with liberal capitalist development, predominantly socialism. Sources for this position are extensive given that, to a large extent, revolutionary anarchism entered a clear decline in strength. In Europe at least from the 1920s, "anarchists are notable by their absence in mainstream histories of ideas and have found only a place on the fringe in most histories of socialist thought."

Clearly, at the time, anarchists did not accept that the decline of revolutionary anarchism would be irreversible and sought to learn from the failures of the period as a means of strengthening its future prospects. They believed that the injustice and inequality of capitalist or communist societies would inevitably provoke a new wave of revolutionary activity at some point in the future.

This article focuses on the most significant contexts for anarchist revolutionary activity during the period 1917-1923: the 1917 Russian revolution, which was in many ways the inspiration for what was to follow; the social unrest of the Trienio Bolchevique in Spain (1918-1920/1); and the factory occupations of the Italian Biennio Rosso (1919-1920). Although anarchists were also active in other countries where social unrest occurred during this period such as Germany, France, 
and even Hungary, it is clear that Russia started the revolutionary progress and would impact the revolutionary Left throughout the continent and beyon,d while Italy and Spain are countries where the anarchist movement was well developed and in close relationship with revolutionary syndicalist organizations. The conflicts, complications, and dilemmas resulting from the dependence of the anarchist revolutionary praxis on its relationship with the working class is the central theme of this article.

Historian Michael Schmidt subdivided the anarchist movement's history into five waves that "rose and fell in accordance with a more general expansion and contraction of objective conditions for the organized popular classes." The first three waves broadly encompass the classical period: 1868-1894 (Rise of the Broad Anarchist/Syndicalist Movement in the Era of State and Capitalist Expansion), 1894-1923 (Consolidation of Syndicalism and Specific Anarchist Organization in a Time of War and Reaction), and 1924-1949 (Anarchist Revolutions Against Imperialism, Fascism, and Bolshevism). ${ }^{3}$ After the demise of the initial "wave" of anarchism associated with the First International and the national organizations it inspired, predominantly in France and southern Europe, and the many failures of the propaganda of the deed with its counterproductive acts of terrorism to achieve its revolutionary objectives, anarchist activity became based in working-class cultural and economic organizations with its tactics and strategy grounded in revolutionary syndicalist theory.

This article covers the final years of Schmidt's third stage, focusing on the tactics adopted, the problems faced, and, ultimately, the causes of the failures according to the participants themselves - the anarchists involved in the revolutionary movements in the three countries covered. The aim is not to provide a critique of the actions of their opponents (Bolsheviks, Socialists, and governments), but of the failure of anarchists to counteract these and create a force able to bring about revolutionary change. Throughout the article the complexities of the anarchist movement must also be borne in mind, as it is impossible to delve into the multiple interpretations of anarchist tactics that existed in what is by its very nature an eclectic movement, based as it is on the principle of liberty. Some level of generalization is inevitable to achieve a level of clarity, the clearest example being the use of generic terms such as anarcho-communism and anarcho-syndicalism, but, as the article will show, the boundaries between the two tendencies were far from rigid.

The article begins with a brief description of the relationship that evolved between the revolutionary syndicalist and anarchist movements prior to the First World War. This is followed by a brief analysis of the impact the First World War had on the movement, specifically the anarchist position towards the First World War, working at the division over whether to take sides that in reality had its roots in a key aspect of anarchist revolutionary theory-the importance of the political nature of the state in which the anarchist movement needed to develop its ideas. A more repressive state might elicit a more immediate revolutionary response, but 
would not allow for a fuller development of anarchist ideals among the massesas opposed to a simplistic "destroy the state" revolt-or debates on issues such as organization (necessity, form, and nature), nor relations with the labour movement in the press, meetings, conferences, or congresses. The insurrectional nature of the revolutionary act, represented by a violent (and spontaneous) rising of the masses, dominated the mindset of many anarchists during this period, despite leading figures, from Pyotr Kropotkin to Errico Malatesta, warning that the revolution, and therefore the violence, would be a long process and would not "be accomplished by a stroke, in the twinkling of an eye." In fact, beyond generalized sketches, anarchists were also vague on the exact organization of the future society that the revolution was supposed to create. The revolution required "groundwork" and yet "the revolutionary education of the people" was to be "accomplished by the revolution itself." "The masses were expected to be the driving force of the revolution, due to an almost naturally perceived understanding of their position as repressed, with anarchists guiding but not leading the movement. An element of ideological preparation would seem to be essential to help these masses see the way forward and not be diverted away from their revolutionary goal. Furthermore, pre-First World War revolutionary anarchist theory said little about alternative revolutionary movements' involvement. After addressing, these key issues the article then examines the revolutionary situations in the three countries mentioned, looks at the the role of the anarchists, and analyzes the weaknesses within the anarchist revolutionary praxis that played a part in the failure of the movements in each country.

\section{Anarchism and Revolutionary Syndicalism before the First World War}

The growth of revolutionary syndicalism following the creation of the French Confédération Générale du Travail (CGT) in 1895 revitalized the anarchist movement, providing a means to rekindle its influence in the organized labour movement, specifically in the countries in which the Bakunist section of the First International was dominant. ${ }^{6}$ The role of the unions was, therefore, central to any anarchist revolutionary activity, giving them contact with the workers who were expected to bring about social change. However, this also brought with it some dilemmas, as it created a high level of dependence on the syndicalist movement and the workers (urban workers or peasantry) in general. Without influence in the unions, anarchism would be a revolutionary ideology with no revolutionary force. There was a danger that syndicalism would engulf anarchism. Pierre Monatte, the CGT representative at the 1907 Anarchist Congress in Amsterdam, claimed that syndicalism, "unlike socialism and anarchism which preceded it," was based "on actions not theories," making this very point. ${ }^{7}$

The Italian anarchist Malatesta cautioned against the potential danger that syndicalism was by nature reformist and would be looking to negotiate improvements for its members via negotiation with the state and, as such, could dilute the revolutionary zeal of anarchist and non-anarchist workers. He argued that anar- 
chists should actively participate in unions in order to propagate anarchist ideals, although without assuming positions of leadership. Another prominent Italian anarchist, Luigi Galleani, writing the same year as the Amsterdam Congress, stressed that "the educational work to be performed among proletarians...appears not only as a pressing need but one which cannot be delayed." 8 Tellingly, he wrote this before the events covered in this article but he did not change the statement in his 1925 book. In short, revolutionary syndicalism was not an anarchist but a class movement. For anarchists it was a means to an end, a tactic not an ideology. The shared interests and potential benefits of a closer relationship with the labour movement were evident as was the potential for discord, although this remained mainly at the level of debate before 1917. While Schmidt and sociologist Lucien van der Walt claim that class struggle anarchism, "is the only anarchism," the problem is that many anarchists of the period would disagree whilst expressing fear that the class politics associated with syndicalism had the potential to denaturalize anarchism. ${ }^{?}$

\section{The Impact of the First World War (1914-1918)}

Despite its relative growth in influence associated with the revolutionary syndicalist organization in the immediate prewar period the anarchist movement across Europe continued to be divided and largely disorganized and to have relatively little influence among the working classes. In France, anarchists could be found in the syndicalist Confédération Générale du Travail, although their influence had waned significantly in the decade before the war. ${ }^{10}$ In Spain, anarchists played a central role in the creation of the Confederación Nacional del Trabajo (CNT) in 1910; however, by 1914 the movement was once more in "disarray," unable to organize and with most of its leading figures in jail or exile. ${ }^{11}$ In Italy, despite the creation of the Unione Sindacale Italiana (USI) in 1912, the anarchist movement had experienced a decline since the First International and leading militants were forced to live in exile. ${ }^{12}$ In fact, across Europe, despite the impulse given by revolutionary syndicalism, the anarchist movement was dwarfed by socialist parties and unions.

The First World War may have proved the lie to the Second International's claims of internationalism as workers lined up to sign on to fight for their countries in the continental conflict. However, this war was also equally damaging to revolutionary syndicalism and anarchism: working-class internationalism had clearly taken second place to bourgeois-inspired nationalism. Millions of those who were the supposed victims of capitalist exploitation did not hesitate to risk their lives to defend the system but they expected a fairer, albeit still capitalist, society, with homes fit for heroes, up on their return. Despite the initial collapse of social democratic internationalism, it would be the socialist (or labour) parties on a national level that would reap the benefit of their collaboration in the war during postwar European society's reappraisal of the political aims by becoming one of the two main parties, and the party of the working class, in most countries of Western Europe. Nonetheless, the growing number of people disaffected with the apparently never-ending 
slaughter as well as the social and economic crisis it was creating would lead to growing social tension pushing at the gates of revolutionary action.

Within the international anarchist movement, a split emerged in relation to the war with leading anarchist figures led by Kropotkin coming out in favour of an Entente victory, which provoked an immediate response from the majority of anarchists whose chief defender was the Italian Errico Malatesta. Beyond the basic arguments of anarchist anti-militarism and the question of bourgeois nationalism, the debates between the two leading figures - both exiled in London at the timedemonstrate two visions of the revolutionary anarchist project. While there were fundamental differences within the international anarchist movement, all sides agreed on one main point - the realization of an anarchist revolution was still some way off.

Kropotkin felt that victorious German militarism would imperil "both the relative liberties wrested from the state over the last hundred years, and the future possibility of achieving an anarchist society." 13 The Germans must be defeated because although anarchists "wanted the reconciliation of peoples, including the German people, we think that they must resist an aggressor who represents the destruction of all our hopes of liberation." "14 In a war between bourgeois democracy and militarist totalitarianism, anarchists could not be indifferent to the consequences of the latter emerging victorious. The irony that Tsarist Russia was fighting alongside France and Britain to a certain extent only reinforced the issue-Kropotkin knew from personal experience the limitations such a political system placed on the potential for anarchist activity. This argument's logical corollary goes to the very heart of one of anarchism's paradoxes: the need for the movement to be able to operate and promote the evolution of anarchist ideals in a non-anarchist society. If some form of democracy was a prerequisite for anarchist growth, weakening this political system before the movement was ready could lead others to exploit the situation.

Malatesta, on the other hand, condemned Kropotkin's position, not simply from the traditional anarchist position but also because he argued that an allied victory would result in a "clerical-nationalist" revival in France, delaying the prospects of a European revolution. ${ }^{15}$ However, as Carl Levy points out, Malatesta's critique also resulted from his appraisal of the potential for anarchist revolution: anarchism would only be achieved in the longer term. Before this development there needed to be a more general socialist revolution which would allow for the growth of anarchist thought among the populace. To create an anarchist society "men and women had to be free to practice libertarian lives in the workplace, in their families and in their communities, and that would only occur through generations." "The "astonishing and humiliating" way in which workers had lined up to defend the bourgeois states only served to prove this point. ${ }^{17}$ Nonetheless, Malatesta felt that the growing opposition to the war did create the potential for this initial revolutionary advance and advocated the creation of a new International that would bring together socialists, anarchists, and syndicalists that had remained loyal to their 
internationalist principle and the class struggle, thereby uniting the war-weary forces of the working class. The International, La Mondiale, was never created. ${ }^{18}$ Both positions betrayed the reality that an anarchist revolution was not imminent and that it required a period of preparation under a benevolent or non-interfering form of government.

So in 1917 the anarchist movement was divided and weakened as, despite the radicalization of certain elements of the working class, the masses chose to follow, although with increasing fatigue, the patriotic logic of the war. In this context, the February Revolution in Russia was a godsend to the anarchists who welcomed it with great enthusiasm, perhaps without fully acknowledging the complexity of the events it would introduce for Russia, the working-class movement, and revolutionary tactics in general. The revolutionary period brought about by the Russian revolution of 1917 would catch the anarchists unprepared, both physically and organizationally in Russia itself, as well as tactically as shall be seen.

\section{The Russian Revolution of 1917}

This confusion is evident in the position of Kropotkin himself who following the February Revolution, returned to Russia and called for Russians to unite around the Revolutionary government's efforts to continue the war against Germany. This was in spite of the fact that the majority of anarchists in Russia had opposed the war. Kropotkin's position was similar to the Mensheviks in that he appeared to accept the theory of revolutions as a stage of development, although the motivating forces were not simply economic and the changes that occurred were "dependent on prevailing local conditions" rather than some abstract idea on the progress of history itself. ${ }^{19}$ Therefore, the February Revolution was a step towards the creation of a socialist society, but not the last one.

After 300 years of Tsarist absolutism, in which ideas could not be freely circulated and debated among the workers, it was foolish to think that a workforce founded on brutality, repression, and strictly imposed hierarchical leadership would immediately be able to understand the complex route to self-emancipation for all. In 1920, Kropotkin lamented that the destruction of a free press and free elections by the Bolshevik government made the construction of a new society impossible. ${ }^{20}$ Once again, for anarchism to advance from a rebellious spirit born in reaction to tyranny into an ideology that could propose serious and realistic solutions to the inequalities and abuses of capitalist development, it needed to do so in a tolerant society. Kropotkin was living proof of this dilemma who had to flee Russia to develop his ideas in France and the UK. Yet, his 40 years in exile had also distanced him from the reality of the Russian masses. Kropotkin was "increasingly isolated" and his direct influence on events in Russia was limited, in large part owing to deliberate Bolshevik policy (he was forced to leave the capital), but also because his position did not reflect the revolutionary mood of the masses who were moving away from support of the Provisional Government from mid to late $1917 .{ }^{21}$ 
The Bolsheviks were the political force that best represented the increasing radicalization of the workers and peasants and their increasing frustration with broken promises of the Provisional Government, especially in relation to the war as well as the worsening economic situation. As the influence of the moderate leftwing parties, the Mensheviks and the Socialist Revolutionaries (SR), collapsed, especially in the industrial cities, Bolshevik power increased with the growing, yet still numerically inferior proportion of anarchists on their side. The basis for growing Bolshevik was not simply negative, out of opposition to the Provincial Government or fear of the Whites, although this was perhaps the key factor for many, but also arose from the deliberately vague nature of the Bolshevik propaganda aimed at the workers. This may be seen as a deliberate short-term policy, given what later occurred, by party leaders to win over the workers - the unions were still dominated by the Mensheviks and SRs_-yet the confusion over Bolshevik policy was not limited to the anarchists, as within the party ranks there was debate as well. The Bolsheviks rode the rising wave of discontent; they did not create nor initially control it. In the countryside the peasants simply seized the land, whilst in the cities the workers took control of the factories. They were not following any party orders. Policy lines were not clear, with Bolsheviks at the factory or local level often seeming to agree with basic syndicalism as well as anarchist ideals in order to adapt to the needs of the situation. In Russia, Bolshevik tactics confused many anarchists who initially supported Lenin against the Provisional Government as they were drawn to the Bolsheviks by the logic of the social and political situation in Russia in 1917. Both groups opposed the Provisional Government and sought to expand the revolution through soviets and factory committees because at a basic level there was a lot of overlap in their immediate goals. The support for workers' control evident in Lenin's April Theses and subsequently in The State and Revolution published in 1917 eclipsed the insistence on the need for the state, although Lenin assured people that this was a necessary short term tool for transition to communism and, unlike the bourgeois state, would have no permanent army, police force, or bureaucracy ruling over the people. ${ }^{22}$ Anarchist Emma Goldman summarized the Bolsheviks' position: they "clothed themselves with the agrarian programme of the Social Revolutionists and the industrial tactics of the Anarchists. Yet, after the high tide of revolutionary enthusiasm had carried them into power, the Bolsheviki discarded their false plumes." 23 The Bolsheviks acted to enforce their ideas on the revolution, while the anarchists simply waited "for the revolution to eventually lead the way to the utopian ideals." 24 Moreover, the Bolsheviks overwhelmingly outnumbered the anarchists.

Despite the international importance of Kropotkin and Mikhail Bakunin, the anarchist movement was late developing in Russia, evolving from factions of the narodnik groups of the 1870 s and 1880s. A number of anarchist groups had been active during the failed revolution of 1905. Nonetheless, the movement was weak and, given the repressive nature of the Tsarist regime remained disorganized 
while the violence associated with the tactic of the propaganda of the deed which had been rejected by most anarchists in Europe-especially with the rise of revolutionary syndicalism — was still prevalent. Prior to February 1917, the inability to organize either as anarchists or revolutionary syndicalists meant that the libertarian movement was exceedingly weak. Before the war, there may have been as few as 220 anarchists active in the country; however, by 1917, Arshinov claimed there were between 30,000 and 40,000. ${ }^{25}$ According to the anarcho-syndicalist Gregori Maximov, who was also a leading figure of the Petrograd Soviet, the revolutionary situation following the February Revolution, the release of many anarchist political prisoners, and the return of anarchist emigres from abroad soon led to Russia being "covered with a thick, albeit too loosely connected, net of groups. Scarcely a sizeable city did not have an Anarcho-Syndicalist or Anarchist group."26 This may be so but most, if not all, of them had Bolshevik groups. The anarchist movement developed and evolved quickly, but was unable to overcome this initial backwardness and lack of penetration among the masses. When an All-Russian Federation of AnarchoCommunists was eventually formed in early 1918, the Bolshevik consolidation of power was already well advanced and it was about to be directed against the anarchists. It is not clear how much influence it had among anarchists, not to mention the working class as a whole. There was also an All-Russian Confederation of Anarcho-syndicalists and organizations at the local level. There appeared to be an agreement on the need for organization, yet, in general, coordination was lacking and anarchists often acted as individuals within the factory committees rather than representatives of any organization. As if to stress the point, an All-Russian Division of Anarcho-Universalists was set up in the summer of 1920, but at its first meeting a split occurred. The anarcho-syndicalist Boris Yelensky lamented that in general "there was no coordinated aim or program among the many factions." 27 Ideological differences continued to weaken the movement; the need for Federations for both communists and syndicalists is proof of this. Although there were attempts to create a unified organization, this would be too little too late.

Yet, a social revolution was evolving around them, from the bottom up, expressed in the urban centres by the factory committees and elsewhere, by the creation of worker and peasant soviets. Factory committees took the place of reformist unions and soviets eclipsed parliament. ${ }^{28}$ Both were organisms that defended worker control and self-management-democratically elected by, and directly accountable to, the workers. An anarchist delegate to the First All-Russian Congress of Trade Unions in January 1918 claimed the committees were "cells of the coming socialist order, the order without political power." ${ }^{29}$ The Soviet historian Anna Pankratova accepted that in the early days of the revolution "anarchist tendencies were more easily and successfully manifested." ${ }^{30}$ This did not mean that anarchists were dominant or even numerous, but simply that - in the period between the revolutions - there was a moment of flux and confusion in which workers put forward basic ideas and imposed policies that could be interpreted as favourable to 
the anarchist interpretation of how the revolution should develop. The evolution of the factory committees demonstrated this and illuminated that, in believing the worker-led revolution would naturally develop along anarchist lines, anarchists they were deluding themselves.

Factory committees began appearing almost immediately after the February Revolution. By the end of March, they existed in nearly every factory in Petrograd and Moscow. During the revolutionary period, the committees effectively replaced or were overseeing the unions, which were weak, and had been heavily infiltrated by the police during the Tsarist period. In Petrograd, a Central Council for Factory Committees was created and by October there were some 65 such centres in the country. ${ }^{31}$ Anarcho-syndicalists played an important role in the committees, especially in Kronstadt and Vyborg, and supported the idea of workers' control put forward by the committees from the beginning. Their rejection of centralization meant that while their views were popular, more credence was given to the Bolsheviks whose influence on the committees began to grow. In October, the first AllRussian Conference of Factory Committees was held with 66 of the 137 representatives being Bolsheviks. As a result, while the anarcho-syndicalists were active in factory committees, and their number increased throughout late 1917, they were well behind the strength of the Bolsheviks. Nonetheless, the factory committees with their bottom-up organizational approach allowed anarchists more influence than their numbers nationally merited, yet the lack of a national organization on a par with the other socialist groups eventually was a cause of weakness as the committees began to form regional and nationwide organizations.

The first Conference of Factory Committees of Petrograd and its environs was held in May 1917. The main subject for debate at the meeting concerned who should run the factories: the Mensheviks favoured state control while the anarcho-syndicalists and the Bolsheviks supported worker control. However, what workers' control entailed was not fully clarified; indeed, "the whole subject of workers' control in the Russian Revolution is awash in confusion." 32 The Bolshevik trade unionist Lozovsky, who later became General Secretary to the Red International of Labour Unions, claimed that 'Workers' control was the fighting slogan of the Bolsheviks before the October days . . . but despite the fact that workers' control figured in all resolutions, and was displayed on all banners, it had an aura of mystery about it."33

Initially, the factory committees were more concerned with the basic aim "of limiting economic disruption, maintaining production and preserving jobs." 34 As the economic crisis worsened throughout 1917, they increased their control over factory operations, intervening in every sphere of management and becoming part of a "counter-state," but this was largely because of the conditions and the ineffective nature of the Provisional Government. This is how anarchists foresaw the movement should naturally evolve, with the workers released from their shackles advancing towards control of production and transforming the economy and soci- 
ety into a libertarian one. Yet, their belief was not held by many-as the number of representatives at conferences and congresses showed. Ultimately, the workers preferred to trust the Bolsheviks with their future. As Smith has argued in his study of Petrograd, throughout 1917, the Bolsheviks did not initiate nor control the movement instead "it responded to it, trying to steer it in the direction it believed was proper. ${ }^{\prime 35}$ In short, the Bolshevik arguments were more convincing and more directly relevant to the immediate goals of the workers themselves.

Nonetheless, the factory committees were the focus of anarchist revolutionary hopes, even more so than the soviets where, although anarchists were often represented, their influence was minimal in relation to the major parties. The unions also proved resistant to anarchism. Following the February Revolution, the union movement "quickly became Menshevik-dominated," and, at the Third Trade Union Conference in July 1917, voted overwhelmingly to support the Provisional Government. ${ }^{36}$ Bolsheviks enjoyed only $36 \%$ of the vote, with the anarchists and syndicalists receiving much less. However, in the summer of that year, a wave of strikes hit the country demonstrating the growing disillusionment of the workers with the lack of progress in the issues of peace, land, and elections promised by the Provisional Government.

In fact, the immediate objective for most Russians in 1917 was to end the war. The desire for revolutionary change and an end to Russian involvement in the war was what caused anarchists to unite with the Bolsheviks: allowing themselves to believe that Lenin and his vanguard party had become "libertarianized" by the social forces around them and would actually give all power to the soviets and workers' control to the factories. At the third Congress of Soviets held at the beginning of 1918, the Bolshevik leader even stated that in Russia "Anarchist ideas have now taken on living form." ${ }^{37}$

Therefore, it is not surprising that the 1917 October Revolution was seen by most anarchists as "an authentic revolution, taking its impulse from the bottom upward and spontaneously producing the organs of direct democracy," one that "presented all the characteristics of a social revolution with libertarian tendencies." ${ }^{38}$ There were at least four anarchists in the revolutionary military committee that planned the October 1917 uprising and it was an anarchist who led the soldiers that closed down the Constituent Congress in January, 1918. As the Bolsheviks sought to consolidate their power and impose their ideas, the anarchists soon realized that they had helped create a force that they could not control.

\section{The October Revolution and Its Aftermath}

The creation of the Council of People's Commissars (Sovnarkom) in October, 1917 and the Supreme Council of the Economy (Vesenkha) in December of the same year heralded a number of decrees that undermined both the soviets and the factory committees. The state and the Bolshevik party controlled the Soviets and the unions, which, in turn, controlled the factory committees, hierarchy anathema to the anar- 
chists. The decree on workers' control passed in November 1917 and awarded the committees "extensive but only supervisory rights," which did not include the right to manage the factories (although that was what many of the committees were effectively doing at the time). ${ }^{39}$ The First All-Russian Trade Union Convention, held in January 1918, demonstrated how power had shifted since mid-1917. Indeed, 75 delegates were Bolsheviks, 51 belonged to no party, 20 were Mensheviks, seven were left SRs, five were right SRs, and three were anarchists. ${ }^{40}$ The anarchists made much of the importance of their role in the committees; in reality, their influence was limited and they proved impotent to stop the weakening of the working-class movement under the new Soviet Regime. This was because the Congress agreed that "the trade unions must support fully and loyally the policy of the socialists Soviet Government directed by the Soviet of People's Commissars," and voted for the factory committees to be effectively placed under the control of the unions. ${ }^{41}$ The year 1918 saw the increasing bolshevization of the workplace, as the whole revolutionary economic structure was centralized under the state. With opposition to Bolshevik rule in the labour movement effectively outlawed, the Bolsheviks now felt safe to move against their revolutionary opponents. From April, 1918 onwardsthere was increasing opposition from anarchists to the Bolsheviks, in large part due to the escalating repression and arrests they faced from the Cheka (the Soviet secret police) in December 1917.

In the months after the October Revolution, it quickly became obvious to many anarchists that they had been fooled. ${ }^{42}$ Having supported the October Revolution, anarchists then found themselves in a quandary over whether to support the consolidation of Bolshevik rule or oppose it along with counterrevolutionaries. Anarchist thinking had not been prepared for this and many continued to support the revolution by undertaking active roles in soviet and factory committees, convincing themselves that at some point in the future their views would be taken into account. Indeed, Skirda speaks of an "auto-liquidation" of the anarchist movement. ${ }^{43}$

As the Bolsheviks increasingly imposed their party line on the revolutionary Left that had initially supported them, anarchist resistance became more violent and the movement was subjected to further repression. The Black Guards-militarized groups of workers initially set up in the Ukraine as a counterweight to the Bolshevik-controlled Red Army-had roughly 50 units active in Moscow with about 2,000 members and were connected to the Moscow Federation of Anarchist Groups. However, the Bolsheviks had no interest in allowing this growth in anarchist influence which was challenging the relatively weak Bolshevik Party in the capital and in April, 1918 the Cheka launched an attack on the Black Guards Headquarters in Moscow, killing some 40 anarchists, as part of an initial crackdown. ${ }^{44}$ In 1919, anarchists and Left SRs in Moscow created the impressively named Pan-Russian Insurgent Committee of Revolutionary Partisans-the Anarchists of the Underground, which was able to infiltrate the Cheka temporarily. ${ }^{45}$ However, 
the return to terrorist tactics from the Tsarist period only proved that the anarchists had effectively lost all hope of influencing the direction the Soviet Union was taking. In November 1919, the Anarchists of the Underground in Moscow were surrounded by members of the Cheka and blew themselves up. Similar groups in other cities were also soon liquidated. The anti-anarchist repression, including the execution of militants, had started, although it would become more widespread from 1921 onwards. Meanwhile, many Russian anarchists had already begun to look towards the Ukraine where an anarchist-inspired revolution was underway. ${ }^{46}$

The situation in the Ukraine was a "kaleidoscopic process... a complex pattern of overlapping revolutions." ${ }^{27}$ At different times Germans (the Brest-Litovsk Treaty awarded the region to the Second Reich), Ukrainian nationalists, Bolsheviks, Whites, and anarchists were involved in fighting. Led by the anarchist Nestor Makhno, a peasant revolt in the south-east of the region had developed into a fullscale social revolutionary movement, with organization based on a "soviet system." "48 The Makhnovschina was not exclusively anarchist: it was "a motley mass movement inside which all supporters of social revolution could co-exist." ${ }^{\text {"49 }}$ However, the influence of anarchism was clear in its aims and practice: ideologically it preached anti-statism, supporting "the complete self-direction of the working peoples in all their affairs" via "free working councils of peasants and workers organizations." 50

Meanwhile, the Confederation of Anarchist Organizations (Nabat), formed in late 1918, brought together the urban anarchists in the Ukraine as well as leading Russian anarchists such as Volin (real name Vsevolod Eichenbaum). Volin hoped that Nabat would help achieve what he called "united anarchism" by bringing together the different anarchist tendencies into one organization. ${ }^{51}$ According to historian Paul Avrich, many syndicalists refused to join because they worried that the organization would lead to the domination of the anarchist movement by anarcho-communists. ${ }^{52}$ Nabat's goal was to spread libertarian ideas among the workers and peasants by publishing a newspaper, printing anarchist pamphlets, organizing propaganda tours, and maintaining contact with anarchist groups in other countries. It was based on groups or circles rather than individuals and any decision had to be agreed upon by the group. Groups then formed regional or urban federations, with each group electing a delegate to the federations' soviets. Nabat began to send militants to Gulyai-Polye, the centre of the Makhnovschina. However, anarchists that were attracted to the Ukraine from other regions had a limited effect on the Makhnovists, the only exception being Peter Arshinov (sometimes spelt Archinov), who had shared a prison cell with Makhno before the 1917 revolutions. The two determined the ideology of the evolving movement along libertarian lines with the aim of building "a genuine Soviet structure in which the soviets, chosen by the workers will be the servants of the people, executing the laws and decrees that the workers themselves will write." ${ }^{53}$ Worn down by the constant fighting with different factions, once the counterrevolutionary threat to Moscow waned, the Makhnovists 
became victims of their erstwhile allies. In 1921 the movement was finally suppressed by the Bolsheviks and the majority of the leading members were executed. The Ukrainian revolution, the one event anarchists could look on with pride in the Russian revolution, would have a great influence on the international movement over the next ten years as prominent members of the Makhnovschina including Volin, Arshinov, and Makhno himself, escaped into exile, ending up in Paris by the mid-1920s where they made contact with French and other exile groups including the Italians and Spanish.

Nonetheless, what lessons the anarchists of Western Europe could learneven in the more agrarian regions of the South-from a revolutionary-military movement and organized peasant rebellion, was not immediately apparent. The rebellion aligned with the romantic anarcho-communist vision of peasant rebellion, but was not easily transferable to industrializing societies. One relevant factor that was omitted was the Makhnovschina nationalist character; indeed, not only were they fighting against the Tsar, the Whites, and the Bolsheviks, they were also fighting to free Ukraine from Russian imperialism. Parallels with Catalonia are obvious whereas, in Italy, the anarchist movement was stronger in some regions than others - a localized or regional rejection of a centralized government may strengthen a movement based on decentralization and federalism such as anarchism. At the same time, it may also limit the growth of a truly national movement that can challenge the nation state. Once the Bolsheviks had consolidated power elsewhere, they easily defeated the Makhnovists. By 1922, throughout Russia, their unions had been closed down and anarchists had been imprisoned, forced into exile, or killed by the Cheka. Some anarchists, the so-called anarcho-Bolsheviks, converted to Bolshevism, accepting that the revolution required a dictatorial transition period, or at least saw no alternative given the situation. Anarchism in Russia had failed.

Following the failure of anarchism to take hold, a comprehensive anarchist appraisal of where things had gone wrong in Russia immediately began. Goldman, Berkman, and Gorelik focused their critique on the nature of Bolshevik power and its violent repression of the Russian anarchist movement, an argument given weight by Maximoff's book The Guillotine at work. ${ }^{54}$ Kropotkin concluded: "we are learning to know in Russia how not to introduce communism," yet anarchists were still far from providing their own solution to this problem beyond utopian rhetoric. ${ }^{55}$

Arshinov, Makhno, and other exiles formed the Dielo Trouda group in Paris, which began publication of an eponymous journal in 1925 before launching the Platform. The Platform was a program for anarchist action in 1926 and pointed the finger at the Russian anarchists' lack of organization and unity. The Platform began with an analysis of the Russian anarchists' failure:

it was during the Russian revolution of 1917 that the need for a general organization was felt most acutely, since it was during the course of that revolution that the anarchist move- 
ment displayed the greatest degree of fragmentation and confusion. The absence of a general organization induced many anarchist militants to defect to the ranks of the Bolsheviks. ${ }^{56}$

The lack of effective organization resulted from the numerous internal squabbles in the movement. ${ }^{57}$ Although not supporting the organizational aspects of the Platform, Maximoff agreed with their critique of the lack of organization. Volin, as we have seen, had tried to mold the Nabat into a unified anarchist organization (a project he would try to continue from exile in France under the name of Synthesis), but was unable to do so. As a result, there was mistrust between the anarcho-syndicalists who were seen as "anarcho-bureaucrats" influenced by a westernized ideology (syndicalism), the anarcho-communists, many of whom lived in the past, and supported the creation of communes along similar lines to the Narodniki (Populists) in the nineteenth century, and the anarcho-individualists who were accused of not being sufficiently involved in revolutionary activity. ${ }^{58}$ The anarcho-Bolsheviks only added to the confusion.

The disparate anarchist factions worked apart, their inability to create a common front limiting their ability to influence, educate and therefore prepare the masses in a context where other revolutionary political groups had no qualms about directing the masses themselves. There was much wishful thinking and exaggeration of the anarchist nature of the initial period of the Russian Revolution in 1917 and the needs and goals of the masses. The anarchists were revolutionaries and had talked, written, and debated about the need for revolution for decades; however, as events in Russia had demonstrated, they had not developed a clear revolutionary policy. The traditional anarchist concept of revolution, based on faith in the spontaneous action of the masses and their ability to construct the new society as an almost natural occurrence, clearly would not work in these circumstances:

it is not enough just for the masses to embark on the road to social revolution. It must also be ensured that the revolution holds true to its path and objective- the overthrow of capitalist society in the name of the society of free workers. As the experience of the Russian revolution of 1917 has shown us, this is no easy task, mainly because of the many parties attempting to steer the movement in the opposite direction to that of social revolution. ${ }^{59}$

In short, anarchists needed to "find ways of withstanding intense reactionary aggression and of sustaining the revolutionary forces during periods of fighting." ${ }^{\prime \prime}$

Improving organization was not simply as a means of better coordination for the revolution when it came, but also a means to facilitate spreading their ideals among the masses who would be the conduit of any social change. However, or- 
ganizing the different tendencies within the anarchist movement and agreeing on tactics, especially in relation to the masses enshrined in the Labour movement, had not proved possible. Although anarchism grew rapidly during the revolutionary period, it was unable to catch up with the better organized Bolsheviks. Moreover, whereas the Bolsheviks had a clear program to present to the workers, the anarchists did not have a program at all. The soviets and the factory councils would serve as inspirations for anarchists abroad, yet they had easily been subdued by the Bolshevik state. In general, the labour movement had "had sufficient strength to overthrow the old regime, in many of its forms, but they lacked the strength to build their own alternative reality" - the strength, or perhaps the will or the knowledge. ${ }^{61}$ In Russia, it appeared to be all three. There were not enough anarchists to influence events, while "the attractiveness of the Bolshevik political platform," the promises of "Peace, Land and Bread!" and "All power to the Soviets," and "the party's carefully nurtured links with the revolutionary workers" gained Bolsheviks the support that anarchists felt should have been theirs. ${ }^{62}$ The Russian anarchists had been outsmarted and out-maneuvered and never really threatened to stand in Lenin's path.

Outside Russia, anarchist reaction to the October Revolution followed a remarkably similar pattern in the different nationalist and regional anarchist organizations. ${ }^{63}$ To simplify, reactions passed through three phases although the difficulties in receiving reliable information about the events in Russia make it hard to pinpoint the time that any specific shift took place. ${ }^{64}$ Initially, militants of all persuasions welcomed the Bolshevik seizure of power enthusiastically, but this support became increasingly qualified from late 1918 as more information became available about the exact nature of Bolshevism. The final phase began in late 1920, when the formation of national communist parties and debate about the Third International and its union adjunct, the Profintern, brought the true nature of the ideological conflict to light. However, the reaction to events in Russia is not the focus of this article, but the evolution of anarchist thinking on the matter is an important backdrop to the revolutionary movements in Spain and Italy.

\section{Anarchism and Syndicalism in the Spanish Trienio Bolchevique}

In Spain, anarchists' initial reaction to the October Revolution was overwhelmingly positive as in other countries. Significantly, news of events in Russia arrived in Spain at a time of growing social tension, creating a potentially revolutionary situation largely as a consequence of the rapid industrialization which occurred during the First World War. Despite Spain being neutral in the global conflict, its social and economic structure was drastically affected by the phenomenal demands its industries received from both belligerent countries and those countries that they had previously supplied. ${ }^{65}$ The rapid rise in industrial output brought with it a concomitant rise in union strength. Membership of the CNT had been, until then, relatively insignificant, but it now grew from 15,000 in 1916 to 714,028 in 1919. ${ }^{66}$ A taste of what was to follow had been provided by the unsuccessful general strike of August, 
1917. For the next three years, Spain was gripped by a spectacular upsurge in social unrest and agitation in both industrializing and rural areas, which resulted in a rapid expansion in CNT membership with anarchists playing a prominent role.

At a National Congress in December 1919, the CNT provisionally joined the Comintern. Events in Russia had little to do with the causes of the unrest, but they did provide a positive spur to the workers. The period 1918-1920 was labeled Trienio Bolchevique by the historian Diaz de Moral, although, as has been pointed out, the period "wasn't three years nor Bolshevik." ${ }^{\prime 67}$ In reality, the period saw a wave of strikes - including general strikes — as the working class flexed its newly developed muscles, along with rising violence and revolt in the countryside, especially in Andalusia. The strength of the CNT, and the anarchist movement in general, was not well distributed nationally, being centralized in Cataluña (of the 433,746 CNT members represented at the CNT's December 1919 National Congress in Madrid, 251,987 came from Barcelona). ${ }^{68}$ Elsewhere, apart from Andalusia and, to a lesser extent, Valencia, Aragon, Asturias, and Galicia, the movement did not have the strength to lead, or even to organize, a revolutionary movement. Revolution may have been in the pages of anarchist and confederal newspapers, but, in reality, the majority of strikes were over concrete demands for better pay, improved working conditions, and the eight-hour work day. Strikes in support of laid-off colleagues were also common. Despite being initially caught on the defensive, the regional and national government, in tandem with the Employers' Federations, soon re-established control. The social tension and subsequent repression created an environment of conflict but there was no collapse of state and military power as in Russia, or serious revolutionary attempts to take power. The failure of the strike movement to evolve into a revolution would result in acrimonious debate within the anarchist movement in Spain during the 1920s.

Spanish anarchist organization outside the unions was still limited to a local level and took place primarily in the press. In the press different affinity groups spoke of the need to organize "all Spanish Anarchists," although the general argument was that this should start at a local level and then move to a regional level. ${ }^{69}$ In mid-December, 1918, a national anarchist conference was held in Barcelona. According to Manuel Buenacasa, who had been General Secretary of the CNT earlier in the year, the conference recommended that all libertarian workers in Spain should "enter and participate directly and immediately in the labor unions." ${ }^{, 70}$ Most anarchists were workers and already members of the CNT therefore the recommendation seemed to be self-evident. It also depended on what was understood by "participate directly." Should they act as workers supporting workers' day-to-day demands, for eample organizing strikes, or should they look to create a revolutionary spirit in the workers and try to push the movement towards a revolutionary end? Significantly, the conference was held just after a Congress in Sans (Barcelona) relaunched the Catalan Regional Confederation (CRT), at which it was agreed that while the CRT viewed anarchism "with sympathy," anarchists were not to "directly 
intervene in the affairs of the unions" and should "work outside the unions in favor of the emancipation of the working class." 71

The potential conflict over this position was momentarily put aside as the reorganized CRT and the CNT launched a series of strikes, the largest of which was at the Ebro Irrigation and Power Company (known locally as the Canadiense) in Lerida which quickly spread to Barcelona in 1919. What started as a protest over the firing of some workers developed into a general strike that left Barcelona without electricity for 44 days, resulting in the authorities forcing the company to accept the CNT's demands including a pay raise; while in an attempt to avoid further such strikes spreading, the government legalized the eight-hour working day in the factories. ${ }^{72}$ La Canadiense was the most successful strike of the postwar period in Spain and "marked the pinnacle of CNT strength prior to the Spanish Civil War."73 The strike would show both the potential of the CNT and its weaknesses. In its initial stages, the strike "frightened bourgeois opinion" not because of "the violence of the strike (never in a major strike had violence been kept so under control), nor any supposedly revolutionary demands ... but the ordered and disciplined strength of the trade unions." ${ }^{\prime 74}$ The fear of the union's growing strength would lead to a fierce backlash by employers with the help of the local military. The authorities in Catalonia reneged on the agreement to release a number of strikers who had been detained during the strike, and the CNT declared a new general strike. The military, combined with the Somatén (a right-wing paramilitary group) and gunmen in the pay of the employers' federation, then launched a fierce campaign against the union. In an attempt to negotiate a resolution, CNT leaders became involved in a statecreated mixed commission but with little success. The failure of the strike and the acceptance of a form of state arbitration via the mixed commission along with arguments by confederal leaders such as Pestaña and Seguí, led to calls that syndicalist policies needed to dominate in the unions as well as increased criticism of the CNT leadership from radical anarchists. A manifesto by the Catalan Federation of Anarchist Groups in December 1919 argued that "Syndicalism—a means of struggle based on direct action — ends with the implantation of libertarian communism ... Syndicalism as a goal in itself, is nothing." They warned it was a tactic of anarchist revolutionary policy, and that under the leadership of "pure syndicalists" who tended to be interested only in the economic struggle, "the abyss of corporatism or of reformism awaits the unions." ${ }^{\text {"75 }}$

In an effort to paste over the growing divisions at its National Congress held in Madrid in December 1919, the CNT passed a resolution adopting libertarian communism (anarchism) as its ultimate goal—although exactly what the Confederation understood by the term would not be clarified until $1936 .{ }^{76}$ The Congress also debated the CNT's membership of the Communist International, adopting a cautious position of provisional affiliation while waiting to see what principles it would be modeled up on. At the same time, the Congress made clear that it was "a firm defender of the principle that guided the First International, as conceived by 
Bakunin"- thus, clearly not endorsing Bolshevism. ${ }^{77}$ The main debate at the Congress was over a possible merger with the socialist Union General de Trabajadores (UGT) which would unite the Spanish working class in one strong movement. Ultimately, the radical position demanding that UGT members abandon the UGT for the CNT won the day, making unification impossible. In general, the debates in the Congress demonstrated the "enormous eclecticism" in CNT ranks. ${ }^{78}$ This issue must be borne in mind as we look at the debate concerning the anarchist position in relation to syndicalism in Spain - there were not simply two well defined positions, that of the radical anarchists or that of the anarcho-syndicalists. Many found themselves in the middle supporting one side on some issues and the otherside on others, with a number seeming to support both. It would be misleading to simply equate the radical anarchist position with that of the anarcho-communists in Russia-they were directly involved in the union movement but used the unions as a tool or weapon to achieve revolution, believing and their principle funtion action should be to inspire and provoke revolution. ${ }^{79}$ Nevertheless, positions evolved over time in relation to events and were also influenced by regional issues, a factor of particular importance in Catalonia where over half the CNT membership lived. In the short term, debate continued between 1919 and 1922, although the attempt by a small faction of pro-Moscow syndicalists to take over the CNT caused a diversion that temporarily united the different factions.$^{80}$ As the strike movement stagnated in the face of government and employer opposition, many anarchists started to blame the weakening of the workers' resolve on syndicalism's focus on achieving concrete economic goals rather than pressing for a revolutionary change.

After a change in government in March 1922, constitutional guarantees were restored and the persecution of the Confederation eased but did not disappear. The first national meeting of leading CNT delegates since 1919 was held in Zaragoza in June 1922. The Zaragoza conference witnessed the defeat of the small pro-Moscow faction and the CNT's withdrawal from the Profintern. The conference also passed a resolution protesting against the repression of anarchists and syndicalists in Russia. Following the Russian debates, the Conference allowed an initial appraisal of the recent strike movement to be carried out. The national committee accepted that the CNT was suffering a "moral crisis" owing to the lack of a united position and that it was "indisputable that errors, confusion and, possibly fundamental deviations" had "corroded the essence of revolutionary syndicalism." To overcome these problems, prominent members of the Committee put forward a "political motion" which the conference adopted unanimously. The motion argued that the CNT had to involve itself in the politics of the nation, not politics as defined by the other political parties, but politics in general, all issues that affected the lives Confederation members. ${ }^{82}$

However, the political motion would only deepen the conflict between radical and syndicalist anarchists now both unrestrained by their alliance against the pro-Moscow faction. For the radicals the unions, and syndicalism in general, were 
merely a means of achieving their goals, providing the force necessary to challenge capitalism and an environment in which to propagate anarchist principles. ${ }^{83}$ They worried that the union leaders, armed with the Zaragoza "political motion" would divert the CNT from its revolutionary objectives and entre into negotiations with the state. Moreover, there was a fear of the growing "syndicalization" of anarchist militants in the CNT: "The union is a means, better than others perhaps, where anarchism can be enacted and if it is successful ... the union becomes an element of libertarian action and emancipation. However, when the syndical environment, with all its vices, absorbs the anarchist personality, it becomes an obstacle to the realization of the ideal." 84

The Spanish anarchists were finally able to hold a National Congress in Madrid in March 1923. The Congress had ten items on the agenda, including organization (local, regional, and national) and the anarchist position in relation to syndicalism. ${ }^{85}$ National organization was limited to the creation of a Committee of Anarchist Relations rather than a national federation because it was judged to be more important that members should seek to influence actions in their own regions by acting within their specific "affinity groups." The use of "affinity groups" would help maintain their freedom of activity and would allow them to act voluntarily rather than through the direction of a national body. ${ }^{86}$ The National Committee of Anarchist Relations (and the various regional committees) would co-ordinate, but not direct, anarchist activity across regional and local borders. ${ }^{87}$ The Congress supported the need to prepare workers for revolution, yet radical anarchists almost immediately tried to launch the movement into revolutionary action. In July, the National Committee and its Catalan counterpart declared that, since the anarchist ideal had been made clear, it was now necessary to make it a reality "and to do this only required one thing: revolution." Anarchists had to provoke the revolution: "we must be men and free men once and for all." ${ }^{88}$ Either too little time had been allocated to undertake the educational tasks required or not enough had been learnt as revolutionary policy seemed as spontaneous and unplanned as ever.

The Committee's first manifesto, "Anarchists and the present movement", appeared to be a battle-cry for anarchists involved in the ongoing transport strike in Barcelona. ${ }^{89}$ The transport strike was simply one of a series of labour protests occurring during the Summer of 1923 which left the workers exhausted, the unions penniless, and the CNT more divided than ever. Information regarding the events is sparse, contradictory, and a little confusing, but what is clear is the dominant role of anarchists in the social unrest and the growing distance between radicals, led by a faction labelled "anarcho-bolshevik," and the increasingly exasperated leaders of the CNT. ${ }^{90}$ Organized in affinity groups (although not all affinity groups were radical), the main one being Los Solidarios, the anarcho-bolsheviks claimed that the bourgeoisie was on the brink of collapse and that now was the time for revolution. They tried to get CNT support for assaults on banks and other financial institutions in order to buy guns so they could be in a position to bring about the revolution or 
resist a possible military coup. ${ }^{91}$ The social violence that accompanied the strike was one of the excuses used by Primo de Rivera to justify his pronunciamiento of September 13, 1923. Soon after the pronunciamiento, functioning of the CNT and the anarchist local and regional organizations was made impossible by government legislation as press censorship ramped up, resulting in the national Committee of Relations established in 1923 having to go into exile in France. ${ }^{92}$

The de Rivera dictatorship would lead to much debate and division within anarchist ranks over why the revolutionary surge of the immediate postwar period had collapsed and the lessons to be learned. Much of this related to internal issues but similarities with events and outcomes in other countries are evident. Within Spain there was acrimonious debate about the relationship between syndicalism and anarchism_radical anarchists blamed the influence of syndicalism and the apparent lack of anarchist penetration of the unions and the workers' mindset suggesting that the solution was to return to a more "purist" interpretation of anarchism (i.e. divested of the Marxist elements introduced by syndicalism). Syndicalism, lacking a clear ideology, led the workers to negotiate and work with the state to achieve only minimum goals, turning them into reformists. ${ }^{93}$ Others blamed the failure on the radical anarchists' attempts to control the labour movement and enforce an unrealistic revolutionary policy that had little or no chance of success. ${ }^{94}$ The lack of an independent anarchist organization outside the unions meant that divisions among anarchists were felt with greater intensity. These debates have been examined in detail by Elorza and Garner, among others, as part of the process leading to the creation of the Federación Anarquista Ibérica in 1927. ${ }^{95}$ It was precisely an organization where debates on the relationship with the labour movement could take place outside the unions that was lacking in the period from 1917-1923. The experience of 1919-23 showed that merely saying that the CNT was the national anarchist organization caused division and confusion within unions.

At its National Congress in Madrid in 1919, the CNT had declared that its ultimate goal was the implementation of libertarian communism, although it had never clarified exactly what this meant. Contrary to apperances, the anarchist message was in many ways subtler and more complex than that of the Socialists, demanding more active input and sacrifice from the masses as well as at an individual level. Indeed, there was a larger focus on the masses as individuals, to destroy existing society and create a new one. As Orobón Fernández argued, however, the society that this sacrifice would create was ill-defined-the message was weak and needed greater explanation. ${ }^{96}$ The anarchist movement was strong and was in some regions the main ideological influence in the labour movement, but even in Cataluña the strike movement never developed into a revolutionary process that could threaten the Spanish state. How could a revolution be carried out on a local or regional basis when in many areas of Spain the movement had little influence, and the Socialist party and its unions had a far greater hold over the working classes? The Socialist message of gradual change through moderate reform appeared to be 
advancing as well. In fact, the Socialists would work closely with the de Rivera dictatorship and offered a less confrontational and risky path than the "all or nothing" radical anarchist approach. The strength of the movement in Cataluña led militant anarchists to overstate the power of the movement nationally and, as a result, reject any idea of collaboration or negotiation with other labour movements, as had occurred at the 1919 Madrid Congress. In short, despite the relevant strength of the movement, it suffered from a lack of ideological penetration among a sufficient section of the working class, a shortfall exacerbated by regional differences. Furthermore, as would be argued in following years by a number of militants, praxis and theory were often contradictory: anarchists spoke of the need to educate and prepare the working masses for revolution only to immediately launch themselves into revolutionary conflict whenever possible. Acting like men "once and for all" did not make up for the lack of realism and preparation. ${ }^{97}$

\section{The Italian Biennio Rosso}

Primo de Rivera's dictatorship came a year after Mussolini had put an end to the democratic regime in Italy in 1922. Italy had a vibrant anarchist movement which included militants such as Errico Malatesta and Luigi Fabbri, whose articles were widely published in the libertarian press globally. Nonetheless, prior to the war much of the Italian movement could be found outside Italy, in France, England, the USA, or Latin America. The anarchist movement grew exponentially in the immediate postwar period and the anarcho-individualist tendency was weakened as "ethical individualism gave way to organizational efforts." 98 'The Unione Comunista Anarchica (UCA) was created in 1919 at a conference in Florence, changing its name to Unione Anarchica Italiana (UAI) a year later. In 1920 the UAI, together with the anarchist affinity groups in Italy, had 20,000 members and membership of the revolutionary syndicalist Unione Sindacale Italiana (USI) was between 300,000 and 500,000, although their popularity still lagged far behind the Socialist Party $(250,000)$ and the Confederazione Generale del Lavoro (CGL) with two million members. ${ }^{99}$ As in Spain from 1917 to the end of 1920, the libertarians' internationalism led them to believe in the possibility of revolution in Italy-especially during the Biennio Rosso period (1919-1920) of intense social unrest in Italy. There was no revolution, but the social unrest did have clear "revolutionary traits," which led the anarchists, as well as other revolutionary socialists, to believe they were witnessing a possible prerevolutionary period on par with Russia in the period between the 1917 revolutions. ${ }^{100}$

The UAI was a federation of autonomous groups that worked together on issues concerning propaganda and the implementation of a freely accepted program. A corresponding commission existed between Congresses to help relations between groups, but it had no authority. Groups and individual anarchists could make contact with each other directly and were free to carry out any action they wished as long as these were in line with the general program. ${ }^{101}$ However, the Union 
tried, as Volin had proposed in Russia, to "synthesize" the different currents in one homogenous group, a task that was only in its "embryonic stage" as the social unrest reached its height. ${ }^{102}$ The organization became larger, but less coherent.

Some anarchists were also members of the CGL and many were members of the revolutionary syndicalist trade union, the USI, which, like the CNT, had been created before the war. Malatesta was the leading figure in the UAI, and was responsible for the anarchist Union's program adopted at the Bologna Congress in 1920. The Congress resolution on the subject focused particularly on the role of the factory committees, which were seen as "suitable organisms to accommodate, with the revolution, all producers ... in their workplace, to achieve anarcho-communist principles." 103 As in Russia, the factory committees were important as they provided a means of anarchist influence in the workers' movement beyond that which their numbers merited. As well as organizing strikes, they could be used to organize production and distribution following the revolution. The Congress motion argued that the most important issue in "the revolutionaries' minds is food," and, therefore, if the revolution could not ensure the basic need of the population it had little hope of success. ${ }^{104}$ As in other countries, the initial interpretation in Italy of events in Russia was favorable, and this libertarian interpretation of events permeated Italian anarchists' thinking: a "sovietist interpretation of the Bolshevik Revolution seemed to be a confirmation of the decentralized and direct action methods of anarchists and syndicalists." ${ }^{\prime 105}$ The introduction to the report on workers' organizations, written by Luigi Fabbri, stressed the need to "let workers' organizations and political organizations remain independent of each other" and to "occupy ourselves with the work of anarchist comrades (within the unions) to ensure that they increasingly promote revolutionary and libertarian goals." ${ }^{\prime 106}$

Anarchists were actively involved in the factory occupations of September 1920 and in the factory committees during the strikes of 1919-1920, but proved more successful at starting the agitation than directing it towards any clear goal. Malatesta tried to clarify the anarchist position:

We do not want to get into power, neither do we want anyone else to do so [and therefore] after contributing to overthrowing the present regime, our task is to prevent, or try to prevent a new government from arising... If we cannot prevent governments from existing and being established due to our lack of strength ... we strive ... to make such governments as weak as possible. ${ }^{107}$

Again, a lot of sacrifices were asked for without providing a clear plan of what they were for. How would making the government as weak as possible improve the workers' situation? What would the future look like? How would it be constituted to avoid suffering, hunger, and chaos? The Socialists, and the soon-to-be-formed Com- 
munist Party (in January, 1921) had more immediate answers to these questions.

The anarchist answers existed, but were vague. In Italy, there was a recognition of the need for organizational duality, with anarchist organization alongside labour movement organizations for a clear policy on what the relationship between the two movements should be, and for an organism within the unions - the factory committees - that would increase anarchist influence. Factory committees also worked towards preparing for revolutionary action and the administration of production during the process to ensure the basic needs of all. Malatesta had previously rejected syndicalist faith in the concept of the general strike to bring about revolution because of to the ability of the factory owners to survive a lack of productivity much longer than the workers could survive a loss of wages. He now urged the workers not to simply occupy the factories, but to organize trade with each other, to maintain productivity and begin the transition towards a worker-dominated economy. ${ }^{108}$ In Italy, anarchists had created a structure and a plan for revolutionary, action although limitations and divisions meant that putting it into practice proved to be unrealistic.

Political scientist Carl Levy suggests there were three main reasons for the failure of anarchist revolutionary policy in Italy: their "uneven national representation (as in Spain anarchism was far stronger in some regions than others), lack of solid institutions, and internal squabbling." 109 The general similarities with Spain are clear. Levy goes even further with questions that go to the heart of the anarchist doctrine: "anarchism could never guarantee state patronage and possible industrial and land reforms." Italy was a constitutional liberal state providing alternative paths towards the reforms many of the workers desired which were less violent and appeared more clearly attainable, specifically, social democracy. As had been seen in Britain, where the trade unions were at the heart of the labour movement, "class consciousness was directed not towards the destruction of the capitalist state, but towards the integration of the working class within it." "The 1918 November Revolution, and the subsequent role of the SPD in Germany, of the Cartel de Gauch government in France, and of the minority government of Ramsay MacDonald's Labour Party in the United Kingdom provide ample evidence. In Italy and Spain, anarchist support was limited and regionalized, with areas where the gradualist and orthodox Marxism of the Spanish and Italian Socialists was a clear obstacle to revolution.

The socialist position towards the factory occupations was sympathetic, but socialists did not endorse them as they were committed to evolution, not to revolution. Without their support, the movement was marginalized and abruptly ran out of steam. ${ }^{111}$ Anarchists had been outnumbered; they had been at the forefront of the movement and had willed the workers to take control of the factories and push the revolutionary movement forward, yet, the workers obeyed the socialist leaders and abandoned the factories. By October, 1920, with the factories now evacuated, the government moved in on the Italian anarchists, arresting the leader- 
ship of both the UAI and the USI. With the rise of fascism anarchists found it impossible to operate as they were imprisoned, murdered, or forced into exile. ${ }^{112}$

The resolutions of the UAI Congress held in Ancona in November 1921 focused on the lack of ideological influences among the masses and the concomitant domination of the Socialists as well as the rejection of Bolshevik Communism. Moreover, the congress accepted the need to organize anarchists' forces in general so as to improve the propagation of anarchist ideals among the masses. Anarchists active in the socialist CGL were to create "internal nuclei" of anarchist action and propaganda, while anarchists had to find ways to "influence the masses of the different parties" (clearly aimed at the Socialist and the recently created Communist parties), and maintain "cordial relations" with them, especially the younger members and the workers. All this was done in an attempt to facilitate an "improved diffusion of [anarchist] ideas." 113

This need to clarify and improve the dissemination of the anarchist message was an argument repeated in the reflections of the central figures of Italian anarchism including Malatesta, Luigi Fabbri, and Armando Borghi- the former in prison and the latter two in exile after the rise of fascism. The participation of anarchists in the labour unrest was more evident than the influence of their ideas. ${ }^{114}$ Anarchists were good at initiating revolutionary action, but their proposals for the future, even the immediate future, were not convincing enough for the masses to follow them throughout the revolutionary period. Malatesta complained that "we anarchists fell well short of having the sort of strength needed to make the revolution using only our own methods and men; we needed the masses and though they were ready for action, they were not anarchist." 115 Once again, in relation to socialists and communists, anarchists "lacked a practical program capable of being enacted the day after the victorious revolution." 116 And that is perhaps why the Biennio Rosso was "more the end of a dream than the beginning of a revolution." 117 The Italian anarchist Molaschi reflected after the collapse of the factory occupations that "It is not enough to create rebels and then leave them to their blind instincts: we anarchists need to give the workers consciousness, faith and skills. They need to know what they want and where to go." 118 This criticism seems valid for the three situations we have looked at.

\section{Conclusion}

The three situations studied, each with their own idiosyncrasies - in relation to the national situation and the nature of their anarchist movement-provide a clear picture of the main difficulties anarchism as a revolutionary movement faced. Questions of organization were central, not simply for the necessities of the revolutionary action itself, but for the propagation and clarification of anarchist tactics and goals (both in the long and short term). Anarchists appeared ill-prepared and ill-disposed to direct the masses, seemingly hoping to lead by example. Anarchist actions gained support, but the theories penetrated less, especially in relation to Bol- 
shevism in Russia and Socialism in Italy. Internal divisions or confusion resulted. The ability of the Bolsheviks to attract anarchist support should in itself be seen as the result of a lack of organization and a clear message. In Italy, too, a larger and more organized movement was still ill-prepared to direct the labour movement and was dwarfed by its socialist opponents, whose hold on the labour masses steered them down a non-revolutionary path and put an end to the factory occupations. In Spain, the country with the largest anarchist movement, the internal ideological struggle was all the fiercer, taking place in the union movement itself. The relative ease with which the factory committees and the labour movement in general in Russia were undermined, the factory occupation in Italy abandoned, and the union movement in Spain repressed all attest to the weakness of the movement and its inability to create a revolutionary force that could realistically enforce revolutionary change. This required strength, organization, and a clear understanding of why, how, and what kind of change was needed.

The criticism of events in Russia, Italy, and Spain focused mainly on immediate tactics such as the need to organize anarchist forces better, predominantly to be able to convey to the workers what anarchists wanted and how to accomplish it as well as whether the ideological preparation for the revolution was achievable in the short term or not. Similarly, Kropotkin pointed to the need to extend the ideological sophistication of anarchist organizations. This sophistication needed time, yet rash-and sometimes unplanned-actions provoked repression. As the Russian anarchists of the Platform, Malatesta in Italy, and Peiró, Pestaña, and Orobón Fernández in Spain (not to mention many other lesser-known figures in the contemporary anarchist press) argued, this ideological sophistication had not been achieved and the workers had fallen victim to other political factions-Bolshevik, socialist, or syndicalist - who weakened or hijacked their revolutionary fervour. Anarchism had found itself in a dilemma, for its revolutionary praxis to succeed it needed the strength provided by the labour movement which was based on the logic of class, not ideology, and with in which various other ideologies jostled for influence. Yet dependence on the labour movement diluted the libertarian nature of the struggle and meant collaboration with, or at the very least acceptance of, other ideological tendencies which could weaken the revolutionary anarchist praxis.

An anarchist revolution had to be internalized before it could be exteriorized: the labour movement needed to have anarchist ideology as its inspiration and could not simply be the force that carried out the revolution. Revolution needed time for preparation and training and, consequently, the political structure for these activities to take place. If this did not exist, anarchism would simply be a romantic, moral, and philosophical movement against oppression but would lack the clarity to bring about action to put an end to oppression in order to create a fairer society. Organization was needed to communicate anarchist ideology clearly to the working masses, as was a more active leadership role during any revolutionary situation to manage the transition period. After the revolution, it would also be vital to provide 
a coherent and credible explanation of how basic services and necessities would be maintained rather than propagating generalized Utopian vision — such a vision might have served in pre-revolutionary times, but would be too vague once the revolutionary situation had arrived which would allow other political groups with more concrete ideas (or, indeed, propaganda) to take the initiative.

In this way, Anarchists were unprepared for revolution, having not taken the time either to educate the working masses sufficiently in their ideology or to plan for the aftermath. Inspired by events in Russia and supported by revolutionary socialists, they threw themselves with vigour into situations of social unrest, seeing revolution within reach. All too often the postwar anarchist movement is seen as having been in a struggle with Bolshevism, yet it was the inability of both radical ideologies to "revolutionize" sufficient numbers among the socialist ranks that was the real cause of their weakness. Blaming syndicalists, communists, and socialists and, of course, state opposition for anarchists lack of success could not disguise the complete failure of traditional anarchist revolutionary theory. The one bright light of the Makhnovist revolution itself emphasized the distance between the romantic revolutionary policy of the past and the stark reality of the industrializing societies of Southern Europe and indeed Russia — a point that its leading exponents tacitly accepted in the Platform. What was needed were solutions to mistakes that, to many anarchists involved, were starting to look like errors of theory and practice exposed in Russia from 1917 to 1922 and thereafter in Spain and Italy. Anarchist tactics had been left behind by the evolution of global political and economic relations. The premature revolutionary action had not simply failed, it had helped to create governments that would make the organization and propagation of anarchism almost impossible. From 1922 onwards, leading Italian anarchists started to arrive in France where they would be joined by Russian and Spanish exiles fleeing from repression who would move beyond an analysis of past failures and towards solutions inaugurating a period of revision of theory and tactics that would continue until the next decade.

This article has analyzed anarchists' interpretations of the multiple failures anarchism experienced following their involvement in the Russian Revolution and social unrest in Spain and Italy. The criticism implicit in these interpretations would be replaced by a far-reaching revision of tactics as anarchists attempted to find clear solutions to the perceived errors in their praxis. The social radicalization of the later war years created potential revolutionary situations across Europe in particular, leading to often spectacular growth in anarchist and anarcho-syndicalist movements. But anarchists, who had long considered themselves to be the only revolutionary option, given the clearly reformist evolution of Social Democracy before, and indeed during, the First World War, suddenly found themselves fighting alongside a new revolutionary force, Bolshevism, itself evolving rapidly from 1917. The relationship between Bolshevism and anarchism was initially close, both in terms of action and, with a libertarian twist, ideology, and would be the cause of subsequent 
confusion, disorientation, and guilt. In Russia, the Bolsheviks initially seemed to embody a number of libertarian principles and tried to attract anarchists to the revolutionary movement who would guide the revolution, only to turn on them once power had been consolidated. Anarchists, across the continent and beyond, were united in their condemnation of the Bolshevik bureaucratic, dictatorial one-party state that had crushed the social revolution and betrayed the workers of Russia. However, even the satisfaction they felt at having anarchist predictions of the inherently dictatorial and elitist basis of Marxist thought proved correct did not hide the reality that the anarchist revolutionary model had failed in Russia and, subsequently, across Europe.

The latter years of Schmidt's second wave of the anarchist movement's history from 1894-1923 saw the pinnacle of anarchism as a revolutionary movement of the masses in Europe, with only Spain from 1936-1937 proving the exception. However, it also exposed the serious flaws in its classical praxis. The definition of Schmidt's third wave (1924-1949) was Anarchist Revolution Against Imperialism, Fascism, and Bolshevism. On the basis of this article, for Europe at least, perhaps 'Resistance and Profound Revision' would be more apt. 


\section{NOTES}

${ }^{1}$ An analysis of this position is provided by Steven Hirsch and Lucien van der Walt in their introduction to Anarchism and Syndicalism in the Colonial and Postcolonial World 1870 - 1940 (Leiden: Brill, 2010). The most famous example being the Marxist historian Eric Hobsbawm, Primitive Rebels (Manchester: Manchester University Press, 1959) and Revolutionaries (London: Phoenix, 1994).

${ }^{2}$ Ruth Kinna, Kropotkin Reviewing the Classical Anarchist Tradition (Edinburgh: Edinburgh University Press, 2016), 2.

${ }^{3}$ Michael Schmidt, Cartography of Revolutionary Anarchism (Oakland: AK Press, 2013), 12-16.

4 Pyotr (Peter) Kropotkin, The Conquest of Bread (London: G.P. Putman's Sons, 1906), 43. https:/ / theanarchistlibrary.org/library/petr-kropotkin-the-conquest-ofbread. For Malatesta see for example, "Revolution in Practice," in The Method of Freedom: An Errico Malatesta Reader, ed. Davide Turcato (Oakland: AK Press, 2014) 419-424. The article originally appeared in Umanita Nova, October 7, 1922.

${ }^{5}$ Petr (Peter) Kropotkin, The Great French Revolution, $1789-1793$ (New York: G.P. Putman's Sons, 1909), 241.

${ }^{6}$ F.F. Ridley, Revolutionary Syndicalism in France (Cambridge: Cambridge University Press, 1970) and the first volume of Jean Maitron, Le Mouvemen anarchiste en France, 1: Desorigines à 1914 (Paris: Libraire François Maspero, 1975), 249-311.

7 The International Anarchist Congress held at the Planius Hall Amsterdam on August 26-31 1907 (London: Freedom Press, 1907), contains a brief outline of Monatte's speech. For the full speech see 'Discurso al Congreso anarquista de Amsterdam,' in Cuadernos de Ruedo Ibérico, El Movimiento libertario español - Pasado, Presente y Futuro (Paris: Ruedo Ibérico, 1974), 86-92.

${ }^{8}$ Luigi Galleani, The End of Anarchism? (Orkney: Cienfuegos, 1982), 63-65.

${ }^{9}$ Lucien van der Walt and Michael Schmidt, Black Flame: The Revolutionary Class Politics of Anarchism and Syndicalism, (Oakland: AK Press, 2009), 19. The Spanish anarchist Ricardo Mella argued that "We anarchists can and must say: the revolution that we envisage goes beyond the interest of one specific class; it wants to achieve the complete liberation of humanity, from all political, economic and moral bondage," in Mella, "La Lucha de Clases," Acción Libertaria (Madrid), December 12, 1913.

${ }^{10}$ Vadim Damier, Anarcho-syndicalism in the 20 $0^{\text {th }}$ Century (Edmonton AB: Black Cat, 2009), 42. See also David Berry, A History of the French Anarchist Movement, 1917 to 1945 (Oakland: AK Press, 2009), 15-35.

${ }^{11}$ James Michael Yeoman, "The Spanish Anarchist Movement at the Outbreak of the First World War: A Crisis of Ideological neutrality” in Shaping Neutrality throughout the First World War, ed. J-L. Ruiz Sánchez, I. Cordero Olivero, and C. García Sanz, (Seville: University of Sevilla, 2015), 83-101. 
${ }^{12}$ Carl Levy, Gramsci and the Anarchists (Oxford: Berg, 1999), 9. Anarchists were involved in anti-militarist protests, playing a prominent role in the Red Week disturbances in Italy in June, 1914. However, at its peak the movement could claim at most 10,000 members.

13 Matthew S. Adams, "Anarchism and the First World War," in Carl Levy and Matthew S. Adams, eds. The Palgrave Handbook of Anarchism (Basingstoke: Palgrave MacMillan, 2018), 389-408.

${ }^{14}$ Peter Kropotkin and Jean Grave, Manifesto of the Sixteen (1916), https:/ /www.marxists.org/reference/archive/kropotkin-peter/1916/sixteen.htm.

${ }^{15}$ Kinna, Kropotkin, 177-183 and Carl Levy, "Malatesta and the war interventionist debate 1914-1917: from the 'Red Week' to the Russian revolutions," in Levy and Adams, The Palgrave Handbook, 69 -92.

${ }^{16}$ Carl Levy, "Malatesta," in Levy and Adams, The Palgrave Handbook, 85-86

${ }^{17}$ E. Malatesta, "Italy Also," Freedom, June 1915.

${ }^{18}$ An attempt by the Spanish anarchists to launch a new Syndicalist International to organize opposition to the war also failed, see Jason Garner, Goals and Means: Anarchism, Syndicalism and Internationalism in the Origins of the Federacion Anarquista Ibérica (Oakland: AK Press, 2016), $71-75$.

${ }^{19}$ Kinna, Kropotkin, 194.

${ }^{20}$ Jane Burbank, Intelligentsia and Revolution Russian Views of Bolshevism, 1917-1922 (New York: Oxford University Press, 1986), 181.

${ }^{21} \mathrm{Jim}$ MacLaughlin, Kropotkin and the Anarchist Intellectual Tradition (London: Pluto, 2016), 239.

22 Arthur Lehning, Marxismo y anarquismo en la revolución rusa (Buenos Aires: Annares, 2008), 102, Vladimir Lenin, The State and Revolution, (1918), available at https://www.marxists.org/archive/lenin/works/1917/staterev/.

${ }^{23}$ Emma Goldman, My Disillusionment with Russia (New York: Doubleday, Page \& Company, 1923), 2.

${ }^{24}$ Frank Jacob, Emma Goldman and the Russian Revolution. From Admiration to Frustration (Berlin and Boston: de Gruyter Oldenbourg, 2020), 63.

${ }^{25}$ Peter Arshinov is cited in Alexandre Skirda, Les Anarchistes dans la révolution russe, (Paris: La Tête de Feuilles, 1973), 23-24, and Carlos Taibo, Anarquismo y Revolución en Rusia, 1917-1921, (Madrid: Catarata, 2017), 49.

26 Grigori Maximoff, Syndicalists in the Russian Revolution (1950), 5, available at http:/ / libcom.org/files/Syndicalists\%20in\%20the\%20Russian \%20Revolution.pdf. 27 Boris Yelinsky, In the Social Storm Memoirs of the Russian Revolution (2013) https://web.archive.org/web/20160305041026/http://blog.globaltoad.com/wpcontent/uploads/www.radicalpress.com/indexf27a.html?page_id=501, 81.

28 A. D'Agostino, "Anarchism and Marxism in the Russian Revolution," in Levy and Adams, The Palgrave Handbook, 409-428, Tiabo, Anarquismo y Revolución, 84. The 
author gives an excellent overview of the anarchist interpretation of the role of the soviets and factory committees in chapter 4, 68-97.

${ }^{29}$ R.M. Jones, The Experience of the Factory Committees in the Russian Revolution (Cardiff, Wales Scorcher Publications, 1984), 21.

${ }^{30}$ Daniel Guérin, Anarchism From Theory to Practice (New York: Monthly Review Press, 1970), 90.

${ }^{31}$ Jones, Factory Committees, 3-4.

${ }^{32}$ S.A. Smith Red Petrograd, Revolution in the factories 1917-1918 (Cambridge: Cambridge University Press, 1983), 139.

${ }^{33}$ From the pamphlet Workers' Control, published by the Socialist Publishing House in 1918 and reproduced in Maximoff, Syndicalists in the Russian Revolution, 8.

${ }^{34}$ Smith, Red Petrograd, 157.

35 Smith, Red Petrograd, 256-261.

${ }^{36}$ Jay B. Sorenson, The Life and Death of Trade Unionism in the USSR, 1917-1928 (New Brunswick, NJ: Aldine Transaction, 2010), 11.

${ }^{37}$ Guérin, Anarchism, 51.

${ }^{38}$ Guérin, Anarchism, 82.

${ }^{39}$ Sorenson, Life and Death, 68.

${ }^{40}$ Smith, Red Petrograd, 114.

${ }^{41}$ Sorenson, Life and Death, 31.

${ }^{42}$ See Voline, The Unknown Revolution: 1917-1921 (Oakland: PM Press, 2019). Voline's basic arguments are summarized by Iain McKay in his introduction to the 2019, edition 11-24. For a detailed appraisal of the Bolshevik takeover of the factory committees and destruction of workers' control see Maurice Brinton, The Bolsheviks and Workers' Control 1917-1921: The State and Counter-Revolution (London: Solidarity, 1970).

${ }^{43}$ Skirda, Les anarchistes, 41.

44 G.P. Maximoff, The Guillotine at Work: Twenty Years of Terror in Russia (Chicago: Globus, 1940), 405-411. In a letter to Albert Thomas, the French communist Jacques Sadoul wrote that the "anarchist party ... is the most active ... and probably the most popular ... and is gaining ground in the city," reproduced in Franz Mintz, ed. Anatol Gorelik: El anarquismo en la Revolución Rusa (Buenos Aires: Anarres, 2008), 37.

${ }^{45}$ Vyancheslav Azarov, Kontrrazvedka, The Story of the Makhnovist Intelligence Service (Edmonton, AB: Black Cat Press, 2008), 16-17.

${ }^{46}$ The term anarco-bolshevik was coined by the Ukrainian anarchist Anatol Gorelik, in his work El anarquismo, 98.

${ }^{47}$ Colin Darch, Nestor Makhno and Rural Anarchism in Ukraine, 1917-1921 (London: Pluto, 2020), 147.

48 Aleksandr Shubin, "The Makhnovist Movement and the National Question in 
the Ukraine, 1917-1921," in Anarchism and Syndicalism, ed. van der Welt and Hirsch, 147-191.

${ }^{49}$ Alexandre Skirda, Nestor Makbnno: Anarchy's Cossack (Edinburgh: AK Press, 2004), 332.

${ }^{50}$ Peter Arshinov, History of the Makhnovist Movement, 1918-1921 (London: Freedom Press, 1987), 81.

${ }^{51}$ Paul Avrich, Russian Anarchists (New Jersey: Princeton University Press, 1967) 205, available at http://www.ditext.com/avrich/russian/anarchists.html.

${ }^{52}$ Avrich, Russian Anarchists, 204-234.

${ }^{53}$ Arshinov, History, 210.

${ }^{54}$ Emma Goldman, My Disillusionment and My Further Disillusionment in Russia (New York: Doubleday, Page \& Company, 1924); Alexander Berkman, The Bolshevik Myth (New York: Boni \& Liveright, 1925); Mintz, Anatol Gorelik, and Maximoff, The Guillotine at Work

${ }^{55}$ Peter Kropotkin, "Message to the Workers of the Western world," in Direct Struggle against Capital: A Peter Kropotkin Anthology, ed. Iain McKay (Oakland: AK Press, 2014), 487-491.

${ }^{56}$ Dielo Trouda Group, Organisational Platform of the Libertarian Communists (Dublin: Workers Solidarity Movement, 1989). The Platform was originally published in 1926. ${ }^{57}$ Avrich, The Russian Anarchists, speaks of the "tangled history of personal quarrels and factional strife" among the Russian anarchists, 250.

${ }^{58}$ Taibo, Anarquismo y Revolucion, 60-63. For a more detailed account see Arshinov, History, and Voline, The Unknown Revolution.

${ }^{59}$ Dielo Trouda Group, Organisational Platform.

${ }^{60}$ Ruth Kinna, The Government of no-one. The Theory and Practice of Anarchism (London: Pelican, 2020), 89.

${ }^{61}$ Taibo, Anarquismo y Revolución, 77.

${ }^{62}$ Alexander Rabinowitch, The Bolsheviks in Power: The First Year of Soviet rule in Petrograd (Bloomington: Indiana University Press, 2007), 4.

${ }^{63}$ Berry, The French Anarchist Movement, 36-109; Roberto Carocci, "Le affinità divergenti. L'anarchismo italiano, la rivoluzione russa e il bolscevismo (1917-1921)," Zapruder: Storie In Movimento, no. 44 (September-December, 2017), 11-23 and Garner, Goals and Means, 83-112.

${ }^{64}$ As late as May 1918 Tierray Libertad was complaining about the "unending series of telegrams" giving different opinions on the revolution. See "Al Margen de la Revolución Rusa," Tierra y Libertad, May 22, 1918.

${ }^{65}$ The main problems were caused by inflation and a rapid decline in the cost of living for the labour force, especially when compated to the evident enrichment of the industrialists. With 1913 prices as an index of 100, by 1918 prices had increased to 218.2 whereas wages had only risen to 125.6. 
${ }^{66}$ Josep Termes, Històra del moviment anarquista a Espanya (1878-1980) (Barcelona: L'Avenç, 2011), 304.

${ }^{67}$ Ricardo Robledo Hernández, "El trienio bolchevique de Díaz del Moral: Conflictividad y reformismo agrario," Sociedad de Estudios de Historia Agraria-Documentos de Trabajo, May 2019.

${ }^{68}$ Memoria del Congreso celebrado en el Teatro de la Comedia de Madrid, los días 10 al 18 de diciembre de 1919 (Barcelona: Cosmos, 1932), 347-352.

69 "A los Grupos Anarquistas de España”, El Comité de la Federación Anarquista de Catalunya (sic.), Acción Social Obrera, December 13, 1919. "A los compañeros y grupos anarquistas de España”, Grupo "Juventud Acrata” de Barcelona and 'Nueva carta del grupo "Juventud Acrata", Acracia, October 30 and 31, 1918. "A Todos los Grupos Anarquista de España”, El Grupo Acracia, Acracia, November 29, 1918.

${ }^{70}$ Manuel Buenacasa, El movimiento obrero español 1886-1926: Historia y crítica (Paris: Amigos del autor, 1966), 51-52 and Acracia, December 15, 1918. Apart from Buenacasa's limited coverage, sources about this conference are surprisingly limited, even given the context.

${ }^{71}$ Confederación Regional del Trabajo de Cataluña, "Memoria del Congreso celebrado en Barcelona los días 28, 29, 30 de junio y 1 de julio del año 1918” (Barcelona: Imprenta Germinal, 1918).

${ }^{72}$ Chris Ealham, La lucha por Barcelona. Clase, cultura y conflicto 1898-1937 (Madrid: Alianza Editorial, 2005), 86-87.

${ }^{73}$ Garner, Goals and Means, 90.

${ }^{74}$ Pere Gabriel, "Red Barcelona in the Europe of war and revolution, 1914-1930," in Red Barcelona: Social Protest and Labour Mobilization in the Twentieth Century, ed. Angel Smith (London: Routledge, 2002), 56.

75 'Los anarquistas en nuestro puesto,' El Comité de la Federación de Grupos Anarquistas de la Región Catalana, Espartaco (Suplemento to Number IV), November 8, 1919.

${ }^{76}$ Memoria, 347-352.

${ }^{77}$ Memoria, 372-373.

${ }^{78}$ Julián Vadillo Muñoz, Historia de la CNT. Utopía, pragmatismo y revolución (Madrid: Catarata, 2019), 148.

${ }^{79}$ Garner, Goals and Means, 139-140.

${ }^{80}$ Garner, "Separated by an ideological chasm: The Spanish Confederación Nacional del Trabajo and Bolshevik Internationalism following the Russian revolution," Journal of Contemporary European History 15, no.3 (August 2006).

${ }^{81}$ IISG, CNT Archive, Film 174 and 200, Preámbulo y Convocatoria de la Conferencia Nacional-Zaragoza, 4 June 1922.

${ }^{82}$ Preámbulo y Convocatoria de la Conferencia Nacional-Zaragoza.

${ }^{83}$ See for example, "La Federación Comunista Libertaria, a sus comradas y a la opi- 
nión pública," Por la Federación Comunista Libertaria el Comité, Acción Social Obrera, January 28, 1922 and 'La Federación de Grupos Acratas de Levante al pueblo productor en general', Redención, July 6, 1922.

84 "El anarquismo se basta por si solo," Solidaridad Obrera, December 4, 1923. In a similar see also "Ante todos las ideas," Solidaridad Obrera, December 14,1923. This position was also supported by Buenacasa in a series of articles in January and February 1924; "Las secciones y los individuos," January 30, 1924; “El Individuo en el sindicato," February 8, 1924; and “Cambiando de Disco," May 17, 1924 all in Solidaridad Obrera. See also "Insistiendo: En la organización debe haber ideas," Solidaridad Obrera, May 23, 1924.

85 “Congreso Nacional Anarquista," Redención, March 1, 1923. No official report of the congress appeared in the Spanish anarchist press, although a less than flattering account was published in the Madrid-based independent newspaper El Sol: "El Congreso Anarquista Español," and "El Terrible Congreso Anarquista," Ramón Gómez de la Serna, El Sol, March 21 and 22, 1923 respectively.

${ }^{86}$ Mauro Bajatierra, "Del Congreso Nacional Anarquista - Constitutión de Grupos," Redención, April 12, 1923. A similar argument is given by José Vilaverde, the Galician delegate at the congress, in "Consideraciones sobre la vida pasada y futura de la CNT,” Sindicalismo, April 25, 1934.

${ }^{87}$ Crisol, August 25, 1923.

88 "Los anarquistas y el movimiento actual, Los comités de Relaciones Anarquistas de Cataluña y España," Redención, July 7, 1923.

89 "Los anarquistas y el movimiento actual," Los comités de Relaciones Anarquistas de Cataluña y España, Cultura y Acción, June 29, 1923: Acción Social Obrera, July 7, 1923: and Redención, July 12, 1923.

90 The term "anarcho-bolshevik" is open to confusion as it was also applied in different contexts in Russia, France, and Argentina to relate to anarchists sympathetic to Bolshevism. This was not the case in Spain — the anarcho-bolsheviks were a small group of militants dedicated to avenging fallen comrades as well as bringing about the revolution through violent means as quickly as possible. Their apparently contradictory name was given to them by their opponents and was derived from their ill-defined plans to create a revolutionary workers' army to overthrow the state and introduce a form of dictatorship of the proletariat. See César M. Lorenzo, Los Anarquistas españoles y el poder (Paris: Ruedo Ibérico, 1969), 47.

91 Ángeles Barrio Alonso, Anarquismo y anarcosindicalismo en Asturias (1890-1936), (Madrid: Siglo XXI, 1988), 259.

92 Antonio Elorza, "La génesis de la Federación Anarquista Ibérica," Revista de Trabajo, 39 and 40, 44-45 and 45 (1972) 125-6 and M. Teresa González Calbet, La Dictadura de Primo de Rivera. El Directorio Militar (Madrid: Ediciones el Arquero, 1987), 205-209.

${ }^{93}$ Carta Abierta-A los camaradas anarquistas,' Solidaridad Proletaria, April 4, 1925 
and "Lo que debe ser El Productor," El Productor, November 7, 1925.

${ }^{94}$ Manifesto del Comité Regional de Cataluña de la CNT, Solidaridad Proletaria, October 10, 1924. Peiró, Juan, Trayectoria de la CNT, Gijon, Jucar, 1979.

95 See Elorza, La Genesis and Garner, Goals and Means.

${ }^{96}$ V. Orobón Fernández, Economía Libertaria de la revolución. La Organización de la producción, Acción, December, 1925.

${ }^{97}$ The most vocal criticism came from Ángel Pestaña and Juan Peiró - see Ángel Pestaña, Trayectoria Sindicalista, Ediciones Tebas, Madrid, 1974 and Juan Peiró, Escrits 1917-39, Edicions 62, Barcelona, 1975. The criticism of certain anarchists was one of the main causes for the splits that emerged in the CNT in the 1930s see Eulàlia Vega, El trentisme a Catalunya. Divergències ideològiques en la CNT 1930-33(Barcelona: Curial, 1980).

${ }^{98}$ Fausto Buttà, Living Like Nomads: The Milanese Anarchist Movement Before Fascism (Newcastle upon Tyne: Cambridge Scholars Publishing, 2015), 195.

${ }^{99}$ Levy, Gramsci and the Anarchists, 119.

100 Roberto Bianchi, Pace, pane, terra. Il 1919 in Italia (Rome: Odradek, 2006), 9. See also Adriana Dada, Class War, Reaction and Italian Anarchists (Johannesburg: Zabalaza, 1982).

${ }^{101}$ Information contained at the end of "Anarchists' Line within the Trade Union Movement" (Report to the International Anarchist Congress in Paris in 1923) in Turcato, The Method of Freedom, 435-440.

102 Buttà, Living Like Nomads, 196.

103 Congreso de Bolonia de la Unión Comunista Anárquica Italiana Del $1^{\circ}$ al 4 de julio de 1920,

http:/ /www.antorcha.net/biblioteca_virtual/historia/bolonia/indice.html.

${ }^{104}$ Malatesta, "Ancora sulla rivoluzione in practica," Umanita Nova, October 14, 1922 and Anarchists' Line within the Trade Union Movement (Report to the International Anarchist Congress in Paris in 1923) in Turcato, 425-429 and 435-440.

105 Levy, Gramsci and the Anarchists, 206.

106 El Segundo Congreso de la "Unione Anarchica Italiana," Spartacus (Revista de Actualidad Social), Buenos Aires, September 18, 1920.

${ }^{107}$ Malatesta, "La rivoluzione in practica" and "Ancora sulla rivoluzione in practica," Umanita Nova, October 7 and 14, 1922, reproduced in English in Turcato, 419-429. 108 Carl Levy, "Gramsci and Anarchism," in Libertarian Socialism: Politics in Black and White, ed. Alex Prichard, Ruth Kinna, Saku Pinta, and David Berry (London: Palgrave Macmillan, 2012), 96-115.

${ }^{109}$ Levy, Gramsici and the Anarchists, 121.

${ }^{110}$ Donald Sassoon, One Hundred Years of Socialism: The West European Left in the Twentieth Century (New York: New Press, 1996), 30.

${ }^{111}$ David Priestland, The Red Flag: Communism and the making of the modern world (Lon- 
don: Penguin, 2010), 117 and William Pelz, Against Capitalism: The European Left on the March (New York: Lang 2007), 126-128.

112 Marco Masulli, "El sindicalismo de acción directa italiano en perspectiva transnacional: redes militantes y conexiones políticas y organizativas entre Francia y España," Pasado y Memoria. Revista de Historia Contemporánea, 20 (2020), 67-91.

113 “El III Congreso de la UAI," La Antorcha (Buenos Aires), December 23, 1921.

114 “La Memoria de Armando Borghi Sobre Rusia (Leida y aprobada en el Congreso general de la U.S.I. del 5 y 6 octubre)," Nueva Senda, November 10, 1921 and Gianpiero Landi, Armando Borghi: protagonista e crítico del sindicalismo anarchico (Ravenna: Bruno Alpini, 2016).

${ }^{115}$ Errico Malatesta, “Anarchists' Line within the Trade Union Movement (Report to the International Anarchist Congress in Paris in 1923)," Turcato, The Method of Freedom, 435-440.

${ }^{116}$ Errico Malatesta, "Ideale e realtà,” Pensiero e Volontà, February 1, 1924.

${ }^{117}$ Buttà, Living Like Nomads, 187.

${ }^{118}$ Carlo Molaschi, "L'anima anarchica,” Pagine Libertarie, July 20, 1921. 